\title{
Nanocarriers Used Most in Drug Delivery and Drug Release: Nanohydrogel, Chitosan, Graphene, and Solid Lipid
}

\author{
İlaç Dağıtım ve Illaç Salımında En Çok Kullanılan Nanotaşıyıcılar: \\ Nanohidrojel, Kitosan, Grafen ve Katı Lipit
}

\author{
(D) Sibel Ayşı ÖZKAN*, (D) Aylin DEDEOĞLU1, (D) Nurgül KARADAȘ BAKIRHAN2, (D) Yalçın ÖZKAN3 \\ 1 Ankara University, Faculty of Pharmacy, Department of Analytical Chemistry, Ankara, Turkey \\ 2University of Health Sciences, Gülhane Faculty of Pharmacy, Department of Analytical Chemistry, Ankara, Turkey \\ 3University of Health Sciences, Gülhane Faculty of Pharmacy, Department of Pharmaceutical Technology, Ankara, Turkey
}

\begin{abstract}
Over the past few years, nanocarriers have become an ideal solution for safe and efficient drug delivery and release. This is mainly due to the extraordinary characteristics that nanomaterials exhibit when compared with their larger scaled forms. A variety of these carriers are more popular due to their high biocompatibility, ensuring greater efficacy especially in cancer treatments. Nanocrystal, liposomal, and micelle designs of these materials as nanocarriers for drug delivery and release have been extensively researched throughout the past 50 years. Successful applications have not only ensured a greater focus on therapeutic development but also created a new solution available in the pharmaceutical market. Herein, a brief review of research studies focused on nanocarrier materials and designs to achieve superior benefits of drugs for disease treatments is presented. Nanohydrogels, chitosan, graphene oxide, and solid lipid nanoparticle nanocarrier designs and applications are selectively given due to the great attention they have gained from being highly biocompatible and easy-to-manipulate nanocarrier options from organic and inorganic nanocarrier materials. Each summary exhibits the progress that has been achieved to date. With greater understanding of the current state in the development process of these nanomaterials, there is a rising chance to provide better treatment to patients, which is a desperate need in pharmaceutical technologies.
\end{abstract}

Key words: Nanocarrier, drug delivery, nanomaterials, controlled drug release, targeting

öz

Geçtiğimiz yıllarda, nanotaşıyıcılar güvenli ve verimli ilaç dağıtımı ve salımı için ideal bir çözüm haline geldi. Bu, temel olarak nanomalzemelerin daha büyük ölçekli formlarıyla karşılaştırıldığında sergiledikleri olağanüstü özelliklerden kaynaklanmaktadır. Bu tașıyıııların çeșitliliği yüksek biyouyumluluk nedeniyle daha popüler olup, özellikle kanser tedavilerinde daha fazla etkinlik sağlar. Son 50 yıl boyunca, nanokristal, lipozomal ve misel tasarımları bu malzemelerin ilaç dağııımı ve salınımı için çok araştııımıştır. Başarılı uygulamalar sadece terapötik gelişimde daha fazla odaklanma sağlamakla kalmadı, aynı zamanda farmasötik pazarda da mevcut yeni bir çözüm yarattı. Bu çalışmada, nanotaşıyıcılar araştırmaların kısa bir derlemesi ve ilaç tedavisi için ilaçların üstün yararlarını elde etmek için nanohidrojel, kitosan, grafen/grafen oksit ve katı lipid nanoparçacık tasarımları sunulmuştur. Bu malzemeler biyouymululuğu yüksek ve manipülasyonu kolay olmaları sebebi ile son yıllarda en çok tercih edilen nanotaşıyııı malzemeleri olmuştur. İlaç dağııımı ve salınmasında en fazla ilgi çeken bu nanotaşıyıcı malzemeleri, bugüne kadar olan gelişimleri özetlenmiştir. İlaç dağıımı için nanotaşıyıcı intiyacının ve bu nano malzemelerin gelişim sürecinde mevcut durumun daha iyi anlaşılmasıyla, farmasötik teknolojilerinde hastalara daha iyi tedavi sağlama şansı artmaktadır.

Anahtar kelimeler: Nanotaşıyıcı, ilaç dağııımı, nanomalzemeler, kontrollü ilaç salımı, hedefleme

*Correspondence: E-mail: ozkan@pharmacy.ankara.edu.tr, Phone: +90 5338183635 ORCID: orcid.org 0000-0001-7494-3077 Received: 13.06.2019, Accepted: 01.08.2019

๑Turk J Pharm Sci, Published by Galenos Publishing House. 


\section{INTRODUCTION}

Materials that have one or more dimensions lower than $100 \mathrm{~nm}$ are considered nanomaterials.' To be more specific, in 2011 the European Commission defined a nanomaterial as follows:

"A natural, incidental or manufactured material containing particles, in an unbound state or as an aggregate or as an agglomerate and where, for $50 \%$ or more of the particles in the number size distribution, one or more external dimensions is in the size range $1 \mathrm{~nm}-100 \mathrm{~nm} .{ }^{\prime 2}$

Nanomaterials have great research and development/product development potential in medical applications. Some of these applications include DNA/RNA nanotechnology, diagnosis by molecular imaging, biosensing, nanomedicine, and nanocarriers for drug delivery. ${ }^{3} \mathrm{~A}$ considerable number of nanomaterials have been developed, produced, and utilized for these application fields, such as nanohydrogels, chitosan/starch/cellulose nanoparticles, graphene (GR)/GR oxide (GO) nanosheets, iron oxide nanoparticles, gold nanoparticles, cerium oxide nanoparticles, and carbon nanotubes/nanoparticles.

Nanomaterials exhibit extraordinary optical, electronic, and/or mechanical properties when compared with their greater scaled forms. They can differ in color, conductivity, reactivity, surface area to volume ratio, and surface tension from macro forms. Due to this, nanomaterials have attracted the attention of scientists for their potential utilization in vaccines, drug development, and drug delivery. ${ }^{4}$ Over many years, many nanomaterials have been adopted as nanocarriers, i.e. nanohydrogels, oil-in-water (O/W) emulsions, liposomes, and nanoparticles based on synthetic polymers or natural macromolecules. ${ }^{5}$ The very first studies were conducted by Couvreur et al. ${ }^{6}$ and Kreuter and Speiser. ${ }^{7}$ in the late 70 s, where the team exploited polymeric nanocapsules as lysosomotropic carriers and adjuvants.

Drug nanocarriers usually serve two main purposes: targeted drug delivery to specific tissue, organ, or cells and controlled drug release. The foundation of drug delivery is based on biocompatible nanoparticles or nanocapsules and targeting molecules. Biocompatible materials are selected and incorporated to enhance the hydrophilicity of hydrophobic carrier systems or drugs. Targeting molecules are generally antibodies or avidin/biotins that directly target tissue, organs, or cells. Drug release features of nanocarrier systems are provided by the environmentally sensitive structure of the carrier. Controlling drug release ensures paramount therapeutic effect by releasing the delivered drug with high efficiency in the targeted area and preventing any healthy tissue damage that could be caused by some drugs such as chemotherapy agents. ${ }^{8}$ Nanocarriers that have been designed from polymerbased nanoparticles are solid colloidal particles that are approximately 10-500 nm in size. ${ }^{4}$ Drug incorporation into nanocarriers is based on 5 methods: dissolution, entrapment, adsorption, attachment, or encapsulation. ${ }^{9}$ Herein a brief review of nanocarrier systems is given. A summary of the literature including easily manipulated popular nanomaterials that have been adopted as nanocarriers (nanohydrogels, chitosan (CS) nanoparticles, GR/GO nanocarriers, and solid lipid nanoparticles) is given. Nanohydrogels and CS nanoparticle derivatives are the most heavily rotated amphiphilic nanocarrier materials. GR/GO nanomaterials are favored nanocarriers since they are present in a wide range of carrier designs. Finally, solid lipid nanocarriers (SLNs) are currently the most promising and novel lipophilic drug carriers. ${ }^{10}$

\section{NANOHYDROGEL CARRIERS}

Nanohydrogels can be defined starting with the descriptions of macro-scaled hydrogels. Hydrogels are three-dimensional hydrophilic polymer chain networks that are crosslinked. These networks can consist of natural or synthetic polymers and display swelling behavior when introduced to water or physiological fluids. Moreover, they are able to revert to their initial state when removed from the presence of water/ biological fluids.11-13 Due to this unique behavior, hydrogels have gained attention and been adopted in biomedical applications such as drug delivery, drug release, and vaccine design. ${ }^{14}$

Drug delivery and drug release system designs that utilize hydrogels have been and are still considered appealing in medicine due to their crosslink-controlled pore structures. Moreover, physiochemically, hydrogels are very similar to the extracellular matrix of the human body. With also a very high content of water, hydrogels are known to have very high biocompatibility. A main disadvantage is their viscosity, which created an alternative solution: nanohydrogels. These submicron particles made excellent drug carriers that could easily be extruded through an injector needle. In addition, decreasing size ensures an increase in surface area that provides further bioconjugation. ${ }^{11,15}$

Nanogels, in the range of $10-100 \mathrm{~nm}$ size, are small enough to be used as systemic drug carriers. For designs that include clearance of nanogel carriers by kidney filtration the diameter is lower than $10 \mathrm{~nm}$. Drug release to tissue, organs, or cells is through the meshes of nanohydrogels, which are typically between 5 and $100 \mathrm{~nm}$ in size. ${ }^{16}$ Mesh sizes in environmentally dependent designs such as temperature- and $\mathrm{pH}$-sensitive ones change with the stimuli according to the crosslink bond concentration that forms or breaks..$^{15}$ Regulating the breakages of crosslinking bonds that form the initial mesh size of the carriers will provide control of drug release acceleration. Other designs include utilization of the swelling capacity of nanohydrogels. ${ }^{17}$ As swelling continues, mesh sizes increase and gradually release the encapsulated drug. ${ }^{15}$

Nanohydrogel carriers that are environmentally dependent include designs sensitive to $\mathrm{pH}$, temperature, electric field, light, enzyme, calcium, glucose, redox, etc..$^{18}$ In this paper, some of these designs are summarized according to their sensitivity features as below. From this summary, it can be stated that as nanohydrogel carriers there are several popular materials that are prominent when compared with others. In Table 1, materials that receive the greatest attention from scientists are listed. 


\section{Temperature-sensitive nanohydrogel carriers}

Temperature-sensitive nanohydrogel carriers are systems that exhibit swelling behavior that is dependent on temperature changes and are a widely studied field. ${ }^{19}$ A temperaturesensitive drug-release design was reported by Ichikawa and Fukumori20 in 1999. The design consists of a water-soluble hemostatic drug core inside a thermosensitive poly[Nisopropylacrylamide (NIPAAm)] nanohydrogel containing an ethyl cellulose shell. Ichikawa and Fukumori ${ }^{20}$ stated that the mentioned shell could change and revert to its initial size with temperature changes between $30^{\circ} \mathrm{C}$ and $50^{\circ} \mathrm{C}$ in water and that nanohydrogels exhibit positive thermosensitive swelling. The drug release rate is reported to be not only temperature dependent but also nanohydrogel concentration dependent. ${ }^{20}$ A very recent study introduced thermosensitive 5-fluorouracil (5-FU; a chemotherapeutic drug employed for solid tumor treatments) containing methyl cellulose (MC) nanohydrogels for decreased side effects of chemotherapy. In this 2018 study Dalwadi and Pate ${ }^{21}$ produced MC nanohydrogels by a tip probesonicator method from MC hydrogels. 5-FU release depends on both temperature and its biodegradability. Within $48 \mathrm{~h}$ the drug is released in the injected area, preventing a cytotoxic drug burst in a very large area as in conventional chemotherapy. ${ }^{21}$

\section{pH-and/or ionic-strength-sensitive nanohydrogel carriers}

$\mathrm{pH}$ and/or ionic strength sensitivity allows nanocarriers' mesh size to be manipulated according to the environmental $\mathrm{pH}$. Elsaeed et al. ${ }^{22}$ synthesized poly(NIPA-co-AAC) nanohydrogels by inverse microemulsion polymerization method in 2010. On average, the diameter of these nanohydrogels is reported to range between 60 and $80 \mathrm{~nm}$. The team delivers a possible drug release methodology that is $\mathrm{pH}$ dependent through poly (NIPA-co-AAC) nanohydrogel by characterizing its swelling behavior between the $\mathrm{pH}$ values of 4.00 and 8.00 (ionic strength=0.4). That study shows that the nanohydrogels' swelling capacity increased with environmental $\mathrm{pH}^{22}$ In an earlier study, in 2004, Dufresne et al. ${ }^{23}$ reported $\mathrm{pH}$-sensitive poly ( $\mathrm{N}$-isopropylacrylamide) derivative copolymers or poly(alkyl(meth)acrylate) diblock copolymers were produced as indomethacin (a nonsteroidal anti-inflammatory drug), fenofibrate (a drug for treating abnormal blood lipid levels), and doxorubicin (DOX) and aluminum chloride phthalocyanine carriers. PNIPAM copolymers were stated to be synthesized by free radical polymerization while the poly[alkyl(meth)acrylate] diblock copolymers were synthesized by atom transfer radical polymerization. The team carried out both in vitro and in vivo assays. Dufresne et al. ${ }^{23}$ refer to the PNIPAM derivatives as a potential safe alternative to Cremophor $^{\circledR} \mathrm{EL}$, a common carrier for various poorly water-soluble drugs. Furthermore, poly[alkyl(meth)acrylate] derivative [polyethylene glycol (PEG)b-(EA-co-MAA)] nanoparticles were stated to be excellent carriers for hydrophobic drugs that could be used orally. The carrier system is reported to exhibit dissociation behavior with increasing $\mathrm{pH}^{23}$

\section{CHITOSAN NANOCARRIERS}

Chitin is a long-chain polymer derivative [poly (b-(1-4)-Nacetyl-D-glucosamine)] of glucose with significance as the raw material of CS nanocarriers (CSNs). When chitin is deacetylated up to about $50 \%$, it transforms into CS, which has a linear backbone linked through glycosidic bonds. ${ }^{24,25}$ CS's efficient bio-adhesiveness and permeabilization capacity make it one of the most popular nanocarrier materials amongst other hydrophilic polymers. ${ }^{26}$ Moreover, CS is a nanocarrier that has a high loading efficiency of drugs. Based on the protonation of $-\mathrm{NH}_{2}$ at the $\mathrm{C}-2$ position of the $\mathrm{D}$-glucosamine repeat, one of the most important characteristics of CS is its solubility in aqueous acidic media as given in Figure 1.24 Thus, CS nanocapsules provide an effective solution for the delivery of hydrophobic drugs. ${ }^{27}$ All the mentioned features of CS nanoparticles make it an excellent nanocarrier material.

Moreover, CS exhibits $\mathrm{pH}$-sensitive behavior due to the percentage of its acetylated monomers and their distribution in the chains. ${ }^{28}$ This behavior is utilized for controlled drug release by scientists. A common example for this is drug delivery to tumor cells and controlling release since the $\mathrm{pH}$ of tumor cells is significantly lower than that of healthy cells. ${ }^{29} \mathrm{~A}$ summary of the literature that features CSNs as drug delivery systems is provided in Table 2 in chronological order. Production methods for CS carriers differ however, the most common method used being ionotropic gelation, which is based on the capability of polyelectrolytes to crosslink in the presence of counter ions. ${ }^{30}$

As can be seen in Table 2, Fernández-Urrusuno et al. ${ }^{31}$ proposed the use of CS nanoparticles as potential drug carriers for transmucosal delivery in 1999. In their design the team loads insulin into CS nanoparticles to be given nasally to conscious normoglycemic rabbits. It is reported that there was a $40 \%$ reduction in the serum glucose levels. ${ }^{31}$ Aktaş et al. ${ }^{34}$ reported the use of PEG-grafted CS nanoparticles as peptide drug carriers. They observed nanoparticle formation through intermolecular hydrogen bonding in an aqueous solution. The incorporation and release of insulin were dependent on the degree of introduction of the PEG chain on CS and observed sustained release phenomenon over time. ${ }^{52,53}$ Pérez-Álvarez et al. ${ }^{51}$ reported one of the most recent studies in this field revealing the state of art in 2019. Their work exploits the designed CSN as a great candidate for polyoxometalate delivery into tumoral

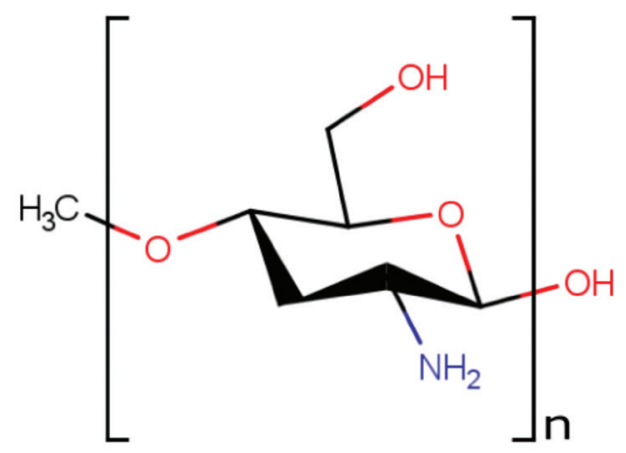

Figure 1. Chitosan monomer 


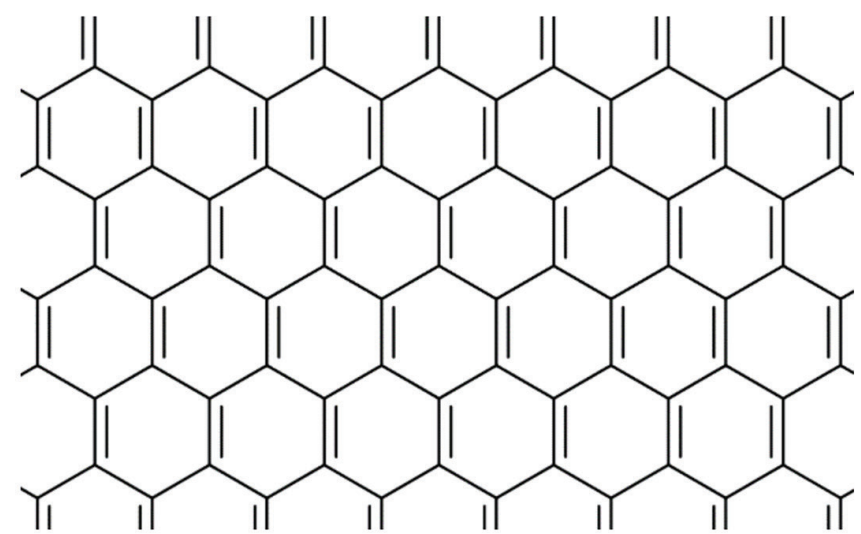

Figure 2. Molecular structure of graphene and graphene oxide

cells. CSN production is achieved by dissolving low molecular weight CS in $1 \%(\mathrm{v} / \mathrm{v})$ acetic acid solutions for crosslinking in inverse microemulsion medium, which results in the attainment of nanometric CS gel particles. Utilizing the $\mathrm{pH}$-sensitive characteristics the team managed to inhibit cytotoxic drug release..$^{51}$

\section{GRAPHENE AND GRAPHENE OXIDE NANOCARRIERS}

Professor Andre Geim and Professor Kostya Novoselov made a groundbreaking disclosure by finally discovering a production method for GR in 2004. The research was outstanding since it had not been possible previously to produce a single layer of graphite (carbon atoms with sp2 bonds in the shape of honeycomb). Later, GR became known as the basic building block of graphitic materials such as spherical nanoparticles that are also known as OD fullerenes, 1D carbon nanotubes, and 3D graphite. ${ }^{54-58}$

Following the discovery, scientists began to reveal GR's unique characteristics provided by its submicron dimension and the $\pi$-conjugation in its structure. GR is revealed to exhibit extraordinary thermal, mechanical, and electrical properties. ${ }^{57}$ Further research provided a better understanding of the physical and chemical structure of GR's surface, which has created interest in medical and pharmaceutical technologies as well as other fields of science. GR is researched and utilized for nanoscaffolds, chemical/biosensing, imaging, drug delivery and controlled drug release.$^{59}$ In the area of nanomedicine and nanocarriers, GR and its composites are important due to its large surface area where every single atom is exposed on the surface $\left(2600 \mathrm{~m}^{2} \mathrm{~g}^{-1}\right)$, layer number, lateral dimension, surface chemistry, and purity. ${ }^{60-62}$ Hereby, GR could be considered a superior candidate as an ideal nanocarrier with the mentioned characteristics that allows a high drug load capacity. ${ }^{58}$

One of the most popular derivatives of GR is GO, GR with oxygen-containing functionalities (epoxide, carbonyl, carboxyl, and hydroxyl groups). GR and GO have a major difference

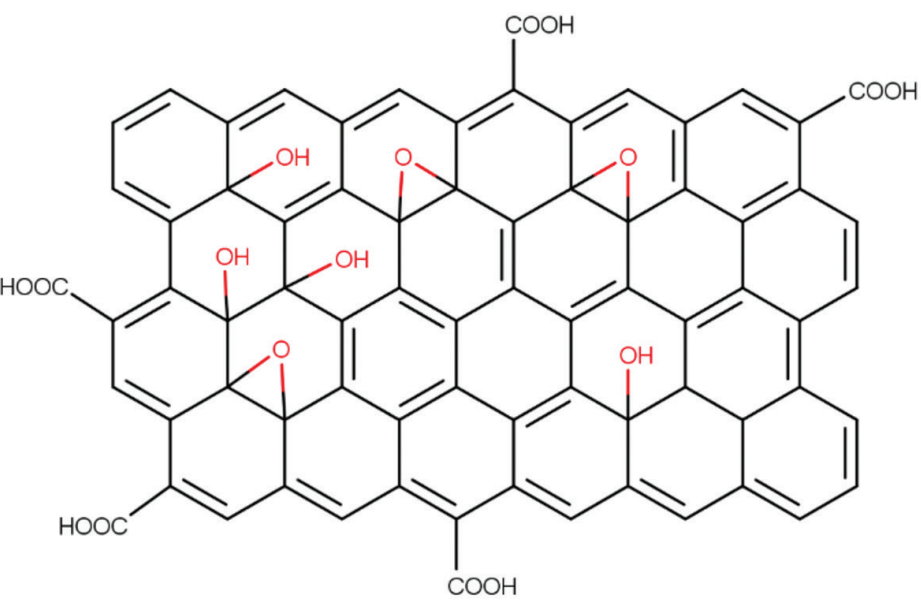

that affects their drug delivery performance when used as nanocarriers: GO is highly hydrophilic, whereas GR is hydrophobic so that it requires surface modifications for use in biological fluids. Thus, any nanocarrier design that uses GR should take into consideration the possible impurities and negative effects such as cytotoxicity. ${ }^{61,63}$ This leads researchers to gravitate towards GO-containing designs rather than GR nanocarrier designs.

In Table 3, a summary of GR/GO nanocarrier designs is given. As can be seen, Hummer's method for production is the most popular choice, where graphite oxidative exfoliation is applied with $\mathrm{NaNO}_{3}$. Although Hummer's production method is usually opted for rather than other complicated methods, over the years it can be seen that nanocarrier designs have evolved into more complex systems that apply chemotherapy and photothermal therapy for treating cancer.

In 2008, Liu et al.87 published a study that demonstrates PEG-functionalized GO nanocarriers used as a noncovalent physisorption chemotherapy drug delivery system. The team reveals that the nanocarriers have an adequate in vitro cellular uptake capacity. ${ }^{87} \mathrm{~A}$ very recent study by Bullo et al. ${ }^{88}$ examined the state of the art in $G O$ nanocarriers. $G O$ is reported to be synthesized by Hummer's method. GO is modified with PEG for higher biocompatibility and loaded with two chemotherapeutic drugs: protocatechuic acid and chlorogenic acid. The carrier is then coated with folic acid to target cancer cells since tumor surface membranes have a greater number of folate receptors. The final size of the nanocarrier system is stated to be $9-40$ $\mathrm{nm}$ with a median of $8 \mathrm{~nm}$. The team reveals that drug release of this design took more than $100 \mathrm{~h}$, which ensures a steady therapeutic effect. ${ }^{88}$

\section{SOLID LIPID NANOPARTICLES}

Nanocarriers designed with a polymer foundation have a certain advantage in terms of the wealth of possible chemical modifications, including the synthesis of block and comb polymers. ${ }^{89}$ Designs that use SLNs exploit this advantage by combining the advantages and avoiding the disadvantages of 
Table 1. Popular nanohydrogel materials utilized as nanocarriers

Nanohydrogel carrier material

Xyloglucan

\section{Structure}

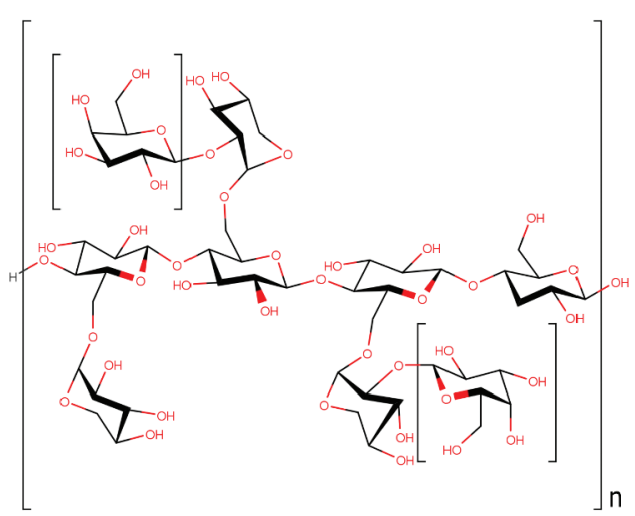

Glycerophosphate<smiles>O=P([O-])([O-])OCC(O)CO</smiles>

Poly (N-isopropylacrylamide)<smiles>CC(C)NC(O)C1CC(C)(CC(C)(C)C)C1</smiles>

Poly (N-isopropylacrylamide-co-acrylic acid)

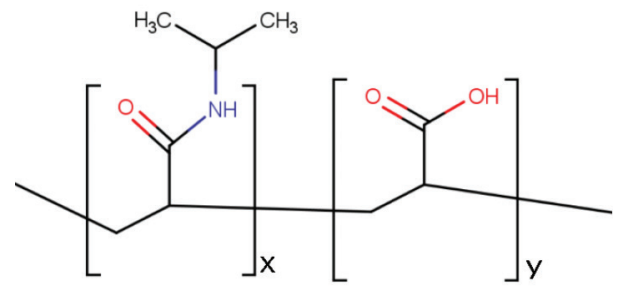

Poloxamer (Pluronic)<smiles>[Y]C(C)(O)COC(C)(C)C(C)OC(C)(C)COC(C)C</smiles>

Poly (Organo phosphazene)<smiles>[R2][PH]([R])(C)(C)=NC(C)(C)C</smiles> 
Table 2. A literature summary of CSNs

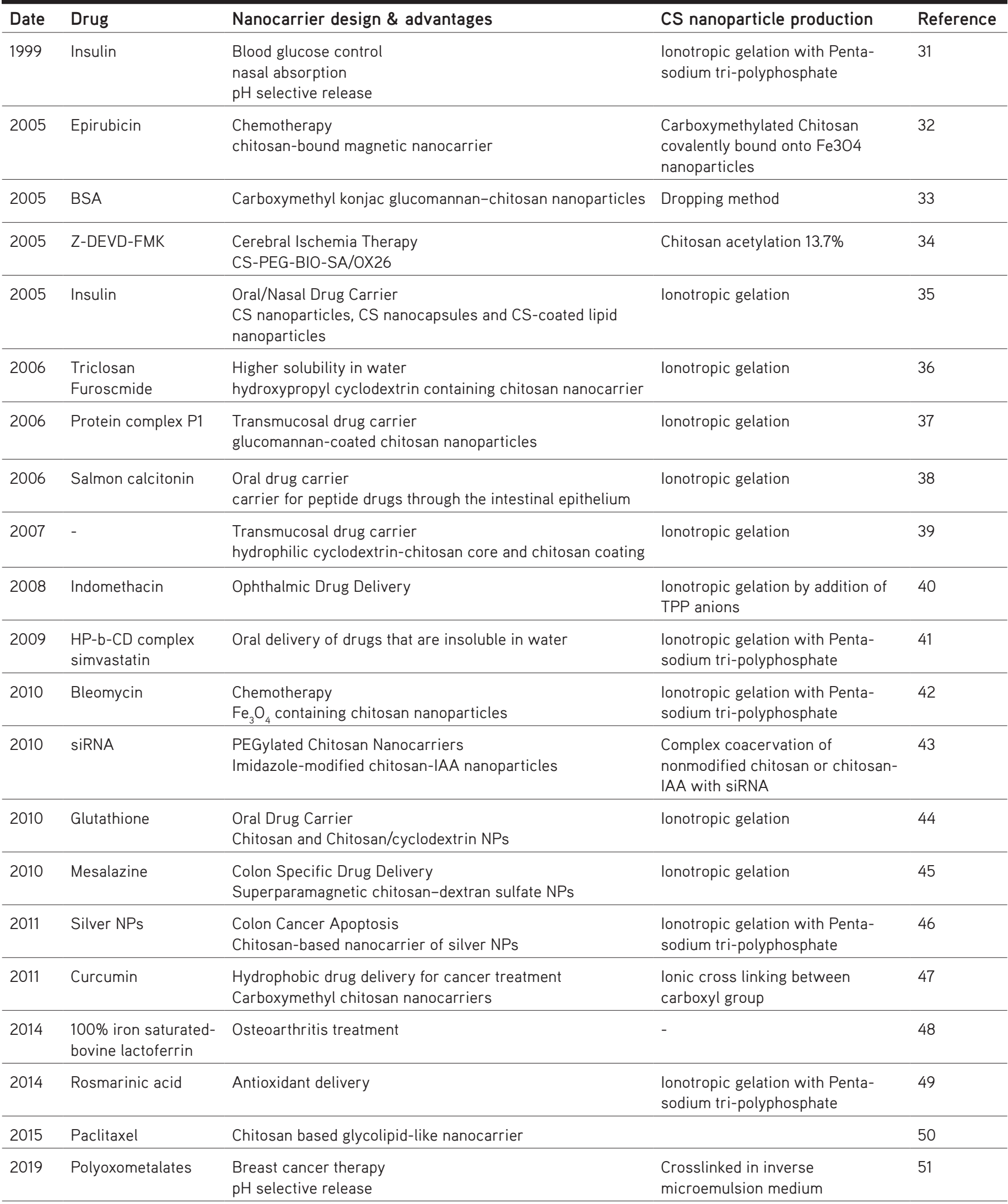

CSN: Chitosan nanocarriers 
Table 3. A literature summary of GR/GO nanocarriers

\begin{tabular}{lll} 
Date & Drug & Nanocarrier \\
\hline 2010 & $\begin{array}{l}\text { Camptothecin (CPT) } \\
\text { Doxorubicin (DOX) }\end{array}$ & $\begin{array}{l}\text { FA-GONS-p-amino } \\
\text { benzenesulfonic acid }\end{array}$
\end{tabular}

Nanocarrier design \&

advantages

Sulfonic acid groups render stability in physiological solutions Target: human breast cancer cells

2011 Ellagic acid (EA) GONS-Pluronic F38(F38), GONS Tween 80(T80), GONSMaltodextrin (MD)
High drug loading (For GO-T80, 1.22 g per $1 \mathrm{~g}$ ) Hummer's method
GR or go synthesis

Hummer's method
Nanocarrier size on average

GONS (thickness) $<150 \mathrm{~nm}$

Reference

64 GONS-T80

(thickness) $=7-8 \mathrm{~nm}$

GONS-MD

(thickness) $=5-6 \mathrm{~nm}$

2011 Doxorubicin (DOX) PEG-GONS

Both chemotherapy

Hummer's 66 and near infrared (NIR) method photothermal therapy Lower systematic toxicity

2011 Tamoxifen Citrate
$(\mathrm{TmC})$

Pyridinium bromide (PY+-Chol)-Graphene (GR)

2013 Doxorubicin (DOX)

\section{Polyethylene} Glycol-Branched PolyethyleneimineReduced GO (PEG-BPEI-rGO)

2013 5-fluorouracil (5-FU) $\mathrm{Fe}_{3} \mathrm{O}_{4}$-GONS

Enhanced the apoptosis

of cancer cells

Photothermally controlled anti-cancer drug delivery Higher cancer cell death

$-\quad$ diar

PY+-Chol-GR 67

(hydrodynamic diameter) $=150-200 \mathrm{~nm}$

Reduction $\quad 100-200 \mathrm{~nm}$ 68 by hydrazine monohydrate

$\mathrm{pH}$ dependent

chemotherapy

High drug loading

capacity of up to 0.35

$\mathrm{mg} \mathrm{mg}^{-1}$

2013 Doxorubicin (DOX)

FA-GONS-Chitosan
$(\mathrm{CHI})$

2013 Doxorubicin (DOX) PVP-GONS-FA

pH sensitive nanocarrie
Both chemotherapy
and near infrared (NIR)
photothermal therapy
High drug loading

\begin{tabular}{ll}
\hline 2014 Doxorubicin (DOX) & GO/integrin aVb3 \\
& mono-antibody (Abs)/ \\
& polyethyleneimine \\
& (PEI)/citraconic \\
& anhydride functionalized \\
& poly(allylamine) $(\mathrm{PAH}-\mathrm{Cit})$ \\
\hline
\end{tabular}

Drug release in acidic intracellular organelles
High drug loading efficiency $(0.98 \mathrm{mg} / \mathrm{mg})$ $\&$ prolonged drug release rate

$\mathrm{pH}$ sensitive drug release

$\begin{array}{llll}\text { Charge-reversal, target } & \text { Hummer's } & \text { GO/PEI/PAH-Cit/ } & 72 \\ \text { specific nanocarrier } & \text { method } & \text { DOX }=20-200 \mathrm{~nm} & \end{array}$

$\begin{array}{lll}\text { Hummer's - } & 71\end{array}$

method

Hummer's GONS=100 nm 70 method 


\begin{tabular}{|c|c|c|c|c|c|c|}
\hline 2014 & Doxorubicin (DOX) & $\begin{array}{l}\text { PEG-Poly (allylamine } \\
\text { hydrochloride) (PAH)- } \\
\text { 2,3-dimethylmaleic } \\
\text { anhydride (DA)-GONS }\end{array}$ & $\begin{array}{l}\text { pH sensitive drug } \\
\text { release } \\
\text { Both chemotherapy and } \\
\text { photothermal therapy }\end{array}$ & $\begin{array}{l}\text { Hummer's } \\
\text { method }\end{array}$ & $\begin{array}{l}\text { PEG-PAH-DA- } \\
\text { GONS=70 nm }\end{array}$ & 74 \\
\hline 2015 & Paclitaxel (PTX) & PEG-GO & $\begin{array}{l}\text { Nontoxic chemotherapy } \\
\text { carrier } \\
\text { Increased biocompatibility } \\
\text { and physiological stability }\end{array}$ & $\begin{array}{l}\text { Hummer's } \\
\text { method }\end{array}$ & $\begin{array}{l}\text { PEG-GO-PTX } \\
\text { (lateral)=50-200 } \\
\mathrm{nm}\end{array}$ & 75 \\
\hline
\end{tabular}

\begin{tabular}{lll}
\hline 2015 & $\begin{array}{l}\text { Irinotecan (IRI) } \\
\text { Doxorubicin (DI) }\end{array}$ & Poloxamer 188-GONS \\
& \\
\hline 2015 & Indomethacin (IMC) & $\begin{array}{l}\text { poly(N- } \\
\text { isopropylacrylamide) } \\
\text { Doxorubicin (DOX) }\end{array}$ \\
& (PNIPAM)-GO
\end{tabular}

Photothermal

therapy with dual

Hummer's GONS=200 nm 76

chemotherapies in one

system

$\begin{array}{lll}2016 \text { Doxorubicin (DOX) } & \text { Gold Nanoparticle } & \text { Targeted chemotherapy } \\ & \text { (AuNP) - Folic Acid - } & \begin{array}{l}\text { and photothermal } \\ \text { ablation }\end{array}\end{array}$

Enhanced thermal
stability
Improved dispersibility in
aqueous and cell medium
Targeted chemotherapy
and photothermal
ablation

$\begin{array}{ll}\text { Hummer's } & \text { GONS=0.85 nm } \\ \text { method } & \text { NIPAM-GONS=3.2 } \\ & n m\end{array}$

$\begin{array}{ll}\text { - } & \text { AuNP-FA-GONS } \\ & \text { (Hydrodynamic } \\ & \text { size) }=188.2 \pm 7.2 \mathrm{~nm} \\ & \text { AuNP-GO } \\ & \text { (diagonal) }=135 \mathrm{~nm}\end{array}$

\begin{tabular}{|c|c|c|}
\hline 2018 & $\begin{array}{l}\text { Doxorubicin (DOX) } \\
\text { Camptothecin (CPT) }\end{array}$ & $\begin{array}{l}\text { Folic acid (FA)- } \\
\text { Graphene Oxide } \\
\text { Nanosheet (GONS) }\end{array}$ \\
\hline 2018 & Tetracycline (TC) & $\begin{array}{l}\text { Carboxymethylcellulose } \\
\text { (CMC)-Zn-Based Metal- } \\
\text { Organic Framework } \\
\text { (MOF-5)-GO }\end{array}$ \\
\hline
\end{tabular}
FA linked GONS for high affinity to

Hummer's

$2.7 \mathrm{~nm}$ folate receptor

2018 Doxorubicin (DOX)

Carboxymethylcellulose
(CMC)-Zn-Based MetalOrganic Framework (MOF-5)-GONS

Efficient oral drug
delivery
Effective protection
against stomach $\mathrm{pH}$

method

$\begin{array}{ll}\text { Hummer's } & \text { CMC/MOF-5/GO } 80 \\ \text { method } & \text { (diameter) }=344 \mathrm{~nm}\end{array}$

Targeted delivery and

\section{Targeted delivery and} controlled release of chemotherapy human blood cancer cell lines

$\begin{array}{lll}\begin{array}{ll}\text { Hummer's } \\ \text { method }\end{array} & \begin{array}{l}\text { GONS } \\ \text { (Thickness) }=30 \mathrm{~nm}\end{array} \\ & \begin{array}{l}\text { CMC/MOF-5/ } \\ \text { GONS=80 nm }\end{array} & \\ & \text { GO=166.5 nm } & 82 \\ \begin{array}{l}\text { Hummer's } \\ \text { method }\end{array} & \begin{array}{l}\text { PVP-GO }=300-400 \\ \mathrm{~nm}\end{array}\end{array}$

$\begin{array}{llll}\text { High biocompatibility } & \text { Hummer's } & \mathrm{GO}=166.5 \mathrm{~nm} & 82 \\ \text { Enhanced anticancer } & \text { method } & \text { PVP-GO=300-400 } & \\ \text { activity within a dosage } & & \mathrm{nm} & \end{array}$
range

Polyvinylpyrrolidone (PVP)-GO
2019 Cis- diamminedichloroplatinum (II) (CisPt)
Maghemite $\gamma-\mathrm{Fe}_{2} \mathrm{O}_{3}-\mathrm{GO}$

\section{Efficient Malignant} glioma chemotherapy GONP accumulates in U87 human glioblastoma subcutaneous tumor xenografts

2019 Methotrexate (MTX)

Polyethylene Glycol bis Amin (PEGA)- GO Magnetic NS (GOMNS)

\footnotetext{
2019 5-Fluorouracil (5-FU) Curcumin (CUR)
}

Chitosan-rGO

Magnetic Iron NPs Increased efficacy in chemotherapy with $\mathrm{pH}$ dependent drug release and biocompatibility

Increased efficiency of

Hummer's
method GO (width) $=80-100 \quad 83$ $\mathrm{nm}$ $\mathrm{GO}$ (thickness) $=6.3$ $\mathrm{nm}$

Hummer's

method chemotherapy against colon cancer GONS-biotin

Targeted therapy for cervical cancer $\mathrm{pH}$-sensitive drug release

$\begin{array}{ll}\begin{array}{l}\text { Hummer's } \\ \text { method }\end{array} & x \text {-Car-GONS-biotin } 86 \\ \text { (thickness) }=219 \mathrm{~nm}\end{array}$

$\begin{array}{ll}\text { Hummer's } & x \text {-Car-GONS-biotin } 86 \\ \text { method } & \text { (thickness) }=219 \mathrm{~nm}\end{array}$ 
other colloidal carriers.

Lipids are defined as molecules that are hydrophobic or consisting of both hydrophilic and hydrophobic parts that are insoluble in water and soluble in organic solvents. ${ }^{90}$ IUPAC gave the following further detailed definition in 1995:

"A loosely defined term for substances of biological origin that are soluble in nonpolar solvents. They consist of saponifiable lipids, such as glycerides (fats and oils) and phospholipids, as well as nonsaponifiable lipids, principally steroids."91

SLNs are developed by researchers as a substitute colloidal carrier with a spherical morphology for drug delivery and drug release. ${ }^{5}$ SLNs have an average size of between 150 and 300 $\mathrm{nm}$ but could reach up to $1000 \mathrm{~nm}$ according to the surfactant used during production and are composed of roughly 0.1-30 (\% w/w) solid fat. ${ }^{92}$ Size and solid to liquid fat ratio affect the long-term stability, drug-loading capacity, and drug-release behavior of SLNs. ${ }^{93}$ As mentioned, SLNs have several favored assets such as low to no toxic effect on healthy tissue and ease of production in greater units of production, ability to load both lipophilic and hydrophilic therapeutic agents, and high drug load capacity. ${ }^{5}$ The most common use of SLNs as nanocarriers is for oral drug delivery. Other than this example, several drugs have been loaded using SLNs for drug delivery, such as doxorubicin and idarubicin, ${ }^{94}$ thymopentin, ${ }^{95}$ and camptothecin. ${ }^{96}$

\section{DISCUSSION AND CONCLUSION}

Nanocarriers provide researchers with a highly applicable alternative method for targeted drug delivery and controlled drug release. The first and foremost reason that nanocarriers have become such a great focus in pharmaceutical technologies is that nanomaterials demonstrate extraordinary characteristics when compared with their larger scaled forms. These characteristics are summarized in this review as color, visible light, reactivity, surface area to volume ratio, conductivity, and surface tension. A variety of these carriers are more popular due to their high biocompatibility, ensuring greater efficacy especially in cancer treatments. Successful applications have not only ensured a greater focus on therapeutic development but also created a new solution available in the pharmaceutical market. In this paper, nanocarrier materials that have gained the most attention in drug delivery and release are summarized under the titles of nanohydrogels carriers, CSNs, GR and GO nanocarriers, and SLNs. Besides these nanomaterials there are also a great number of different nanocarrier designs that are not included in this review, such as gold nanocarriers, ${ }^{97}$ starch and/or cellulose nanocarriers, ${ }^{98}$ cerium oxide nanocarriers, ${ }^{99}$ and carbon nanotube incorporated nanocarriers. ${ }^{100}$ It is clear that, with further information gathered on nanocarriers for drug delivery and the current state in the development process of these nanomaterials, there is a high possibility to deliver better treatment to patients desperate in need of efficient treatment strategies.

Conflict of interest: No conflict of interest was declared by the authors.

\section{REFERENCES}

1. Grimsdale AC, Müllen K. The chemistry of organic nanomaterials. Angew Chem Int Ed Engl. 2005;44:5592-5629.

2. EU Definition of a Nanomaterial [Internet]. [cited 2019 May 27]. Available from: https://www.safenano.org/knowledgebase/ regulation/substances/eu-definition-of-a-nanomaterial/

3. Nalwa HS. A special issue on reviews in nanomedicine, drug delivery and vaccine development. J Biomed Nanotechnol. 2014; 10:1635-1640.

4. Han J, Zhao D, Li D, Wang X, Jin Z, Zhao K. Polymer-based nanomaterials and applications for vaccines and drugs. Polymers (Basel). 2018;10(1).

5. Müller RH, Mäder K, Gohla S. Solid lipid nanoparticles (SLN) for controlled drug delivery - a review of the state of the art. Eur $\mathrm{J}$ Pharm Biopharm. 2000;50:161-177.

6. Couvreur P, Kante B, Roland M, Guiot P, Bauduin P, Speiser P. Polycyanoacrylate nanocapsules as potential lysosomotropic carriers: preparation, morphological and sorptive properties. J Pharm Pharmacol. 1979;31:331-332.

7. Kreuter J, Speiser PP. In vitro studies of poly(methyl methacrylate) adjuvants. J Pharm Sci. 1976;65:1624-1627.

8. De Jong WH, Borm PJ. Drug delivery and nanoparticles: applications and hazards. Int J Nanomedicine. 2008;3:133-149.

9. Ochekpe NA, Olorunfemi PO, Ngwuluka NC. Nanotechnology and Drug Delivery Part 2: Nanostructures for Drug Delivery. Trop J Pharm Res. 2009;8:275-287.

10. Lombardo D, Kiselev MA, Caccamo MT. Smart nanoparticles for drug delivery application: development of versatile nanocarrier platforms in biotechnology and nanomedicine. Journal of Nanomaterials. 2019;2019:1-26.

11. Hoare TR, Kohane DS. Hydrogels in drug delivery: progress and challenges. Polymer. 2008;49:1993-2007.

12. Choudhary B, Paul SR, Nayak SK, Qureshi D, Pal K. Synthesis and biomedical applications of filled hydrogels. In: Pal K, Banerjee I, eds. Polymeric Gels: Characterization, Properties and Biomedical Applications (1 ${ }^{\text {st }}$ ed). United Kingdom; Elsevier, 2018:283-302.

13. Klouda L, Mikos AG. Thermoresponsive hydrogels in biomedical applications. Eur J Pharm Biopharm. 2008;68:34-45.

14. Wang ZG, Ding B. DNA-based self-assembly for functional nanomaterials. Adv Mater. 2013;25:3905-3914.

15. Li J, Mooney DJ. Designing hydrogels for controlled drug delivery. Nat Rev Mater. 2016;1:16071.

16. Lin CC, Metters AT. Hydrogels in controlled release formulations: network design and mathematical modeling. Adv Drug Deliv Rev. 2006;58:1379-1408.

17. Brannon-Peppas L, Peppas NA. Equilibrium swelling behavior of $\mathrm{pH}$-sensitive hydrogels. Chemical Engineering Science. 1991;46:715-722.

18. Garg T, Singh S, Goyal AK. Stimuli-sensitive hydrogels: an excellent carrier for drug and cell delivery. Crit Rev Ther Drug Carrier Syst. 2013;30:369-409.

19. Liu J, Yin Y. Temperature responsive hydrogels: construction and applications. Polym Sci. 2015;1:1. 
20. Ichikawa H, Fukumori Y. A novel positively thermosensitive controlled-release microcapsule with membrane of nano-sized poly(N-isopropylacrylamide) gel dispersed in ethylcellulose matrix. J Control Release. 2000;63:107-119.

21. Dalwadi C, Patel G1. Thermosensitive nanohydrogel of 5-fluorouracil for head and neck cancer: preparation, characterization and cytotoxicity assay. Int J Nanomedicine. 2018;13(T-NANO 2014 Abstracts):31-33.

22. Elsaeed SM, Farag RK, Maysour NS. Synthesis and characterization of $\mathrm{pH}$-sensitive crosslinked (NIPA-co-AAC) nanohydrogels copolymer. J Appl Polym Sci. 2012;124:1947-1955.

23. Dufresne MH, Garrec DL, Sant V, Leroux JC, Ranger M. Preparation and characterization of water-soluble $\mathrm{pH}$-sensitive nanocarriers for drug delivery. Int J Pharm. 2004;277:81-90.

24. Rinaudo M. Chitin and chitosan: properties and applications. Progress in Polymer Science. 2006;31:603-632.

25. Ravi Kumar MNV. A review of chitin and chitosan applications. React Funct Polym. 2000;46:1-27.

26. de la Fuente M, Csaba N, Garcia-Fuentes M, Alonso MJ. Nanoparticles as protein and gene carriers to mucosal surfaces. Nanomedicine (Lond). 2008;3:845-857.

27. Calvo $P$, Remuñán-López $C$, Vila-Jatu JL, Alonso MJ. Novel hydrophilic chitosan-polyethylene oxide nanoparticles as protein carriers. J. Appl. Polym. Sci. 1997;63:125-132.

28. Csaba N, Garcia-Fuentes M, Alonso MJ. The performance of nanocarriers for transmucosal drug delivery. Expert Opin Drug Deliv. 2006;3:463-478.

29. Zhang $X$, Lin $Y$, Gillies RJ. Tumor $p H$ and its measurement. J Nucl Med. 2010;51:1167-1170.

30. Giri TK. Alginate containing nanoarchitectonics for improved cancer therapy. In: Holban AM, Grumezescu AM, eds. Nanoarchitectonics for Smart Delivery and Drug Targeting. Elsevier, 2016;565-588.

31. Fernández-Urrusuno R, Calvo $P$, Remuñán-López C, Vila-Jato JL, Alonso MJ. Enhancement of nasal absorption of insulin using chitosan nanoparticles. Pharm Res. 1999;16:1576-1581.

32. Chang YC, Shieh DB, Chang $\mathrm{CH}$, Chen DH. Conjugation of monodisperse chitosan-bound magnetic nanocarrier with epirubicin for targeted cancer therapy. J Biomed Nanotechnol. 2005;1:196-201.

33. Du J, Sun R, Zhang S, Zhang LF, Xiong CD, Peng YX. Novel polyelectrolyte carboxymethyl konjac glucomannan-chitosan nanoparticles for drug delivery. I. Physicochemical characterization of the carboxymethyl konjac glucomannan-chitosan nanoparticles. Biopolymers. 2005;78:1-8.

34. Aktaş Y, Yemisci M, Andrieux K, Gürsoy RN, Alonso MJ, FernandezMegia E, Novoa-Carballal R, Quiñoá E, Riguera R, Sargon MF, Celik HH, Demir AS, Hincal AA, Dalkara T, Capan Y, Couvreur P. Development and brain delivery of chitosan-PEG nanoparticles functionalized with the monoclonal antibody OX26. Bioconjug Chem. 2005;16:1503-1511.

35. Prego C, García M, Torres D, Alonso MJ. Transmucosal macromolecular drug delivery. J. Control. Release. 2005;101:151-162.

36. Maestrelli F, Garcia-Fuentes M, Mura P, Alonso MJ. A new drug nanocarrier consisting of chitosan and hydoxypropylcyclodextrin. Eur J Pharm Biopharm. 2006;63:79-86.
37. Cuña M, Alonso-Sandel M, Remuñán-López C, Pivel JP, AlonsoLebrero JL, Alonso MJ. Development of phosphorylated glucomannan-coated chitosan nanoparticles as nanocarriers for protein delivery. J Nanosci Nanotechnol. 2006;6:2887-2895.

38. Prego C, Fabre M, Torres D, Alonso MJ. Efficacy and mechanism of action of chitosan nanocapsules for oral peptide delivery. Pharm Res. 2006;23:549-556.

39. Trapani A, Garcia-Fuentes M, Alonso MJ. Novel drug nanocarriers combining hydrophilic cyclodextrins and chitosan. Nanotechnology. 2008;19:185101.

40. Badawi AA, El-Laithy HM, El Qidra RK, El Mofty H, El dally M. Chitosan based nanocarriers for indomethacin ocular delivery. Arch Pharm Res. 2008;31:1040-1049.

41. Vyas A, Saraf S, Saraf S. Encapsulation of cyclodextrin complexed simvastatin in chitosan nanocarriers: a novel technique for oral delivery. J Incl Phenom. 2009;66:251-259.

42. Kavaz D, Odabaş S, Güven E, Demirbilek M, Denkbaş EB. Bleomycin loaded magnetic chitosan nanoparticles as multifunctional nanocarriers. J. Bioact. Compat. Polym. 2010;25:305-318.

43. Ghosn B, Singh A, Li M, Vlassov AV, Burnett C, Puri N, Roy $K$. Efficient gene silencing in lungs and liver using imidazolemodified chitosan as a nanocarrier for small interfering RNA. Oligonucleotides. 2010;20:163-172.

44. Trapani A, Lopedota A, Franco M, Cioffi N, leva E, Garcia-Fuentes M, Alonso MJ. A comparative study of chitosan and chitosan/ cyclodextrin nanoparticles as potential carriers for the oral delivery of small peptides. Eur J Pharm Biopharm. 2010;75:26-32.

45. Saboktakin MR, Tabatabaie R, Maharramov A, Ramazanov MA. Synthesis and characterization of superparamagnetic chitosandextran sulfate hydrogels as nano carriers for colon-specific drug delivery. Carbohydr. Polym. 2010;81:372-376.

46. Sanpui P, Chattopadhyay A, Ghosh SS. Induction of apoptosis in cancer cells at low silver nanoparticle concentrations using chitosan nanocarrier. ACS Appl Mater Interfaces. 2011;3:218-228.

47. Anitha A, Maya S, Deepa N, Chennazhi KP, Nair SV, Tamura H, Jayakumar R. Efficient water soluble O-carboxymethyl chitosan nanocarrier for the delivery of curcumin to cancer cells. Carbohydr. Polym. 2011;83:452-461.

48. Samarasinghe RM, Kanwar RK, Kanwar JR. The effect of oral administration of iron saturated-bovine lactoferrin encapsulated chitosan-nanocarriers on osteoarthritis. Biomaterials. 2014;35:75227534.

49. da Silva SB, Amorim M, Fonte P, Madureira R, Ferreira D, Pintado $M$, Sarmento B. Natural extracts into chitosan nanocarriers for rosmarinic acid drug delivery. Pharm Biol. 2015;53:642-652.

50. Hu YW, Du YZ, Liu N, Liu X, Meng TT, Cheng BL, He JB, You J, Yuan $H, H u F Q$. Selective redox-responsive drug release in tumor cells mediated by chitosan based glycolipid-like nanocarrier. J Control Release. 2015;206:91-100.

51. Pérez-Álvarez L, Ruiz-Rubio L, Artetxe B, Vivanco MD, GutiérrezZorrilla JM, Vilas-Vilela JL. Chitosan nanogels as nanocarriers of polyoxometalates for breast cancer therapies. Carbohydr Polym. 2019;213:159-167.

52. Kumar MN, Muzzarelli RA, Muzzarelli C, Sashiwa H, Domb AJ. Chitosan chemistry and pharmaceutical perspectives. Chem Rev. 2004;104:6017-6084. 
53. Ahmed TA, Aljaeid BM. Preparation, characterization, and potential application of chitosan, chitosan derivatives, and chitosan metal nanoparticles in pharmaceutical drug delivery. Drug Des Devel Ther. 2016;10:483-507.

54. Geim AK, Novoselov KS. The rise of graphene. Nat Mater. 2007;6:183-191.

55. Geim AK. Graphene: status and prospects. Science. 2009;324:15301534.

56. Stankovich S, Dikin DA, Dommett GH, Kohlhaas KM, Zimney EJ, Stach EA, Piner RD, Nguyen ST, Ruoff RS. Graphene-based composite materials. Nature. 2006;442:282-286.

57. Allen MJ, Tung VC, Kaner RB. Honeycomb carbon: a review of graphene. Chem Rev. 2010;110:132-145.

58. Liu J, Cui L, Losic D. Graphene and graphene oxide as new nanocarriers for drug delivery applications. Acta Biomater. 2013;9:9243-9257.

59. Shao Y, Wang J, Wu H, Liu J, Aksay IA, Lin Y. Graphene based electrochemical sensors and biosensors: A review. Electroanalysis 2010;22:1027-1036.

60. Shen H, Zhang L, Liu M, Zhang Z. Biomedical applications of graphene. Theranostics. 2012;2:283-294.

61. Wang Y, Li Z, Wang J, Li J, Lin Y. Graphene and graphene oxide: biofunctionalization and applications in biotechnology. Trends Biotechnol. 2011;29:205-212.

62. Liu Z, Sun X, Nakayama-Ratchford N, Dai H. Supramolecular chemistry on water-soluble carbon nanotubes for drug loading and delivery. ACS Nano. 2007;1:50-56.

63. Pumera M. Nanotoxicology: the molecular science point of view. Chem Asian J. 2011;6:340-348.

64. Zhang L, Xia J, Zhao Q, Liu L, Zhang Z. Functional graphene oxide as a nanocarrier for controlled loading and targeted delivery of mixed anticancer drugs. Small. 2010;6:537-544.

65. Kakran M, Sahoo NG, Bao H, Pan Y, Li L. Functionalized graphene oxide as nanocarrier for loading and delivery of ellagic acid. Curr Med Chem. 2011;18:4503-4512.

66. Zhang W, Guo Z, Huang D, Liu Z, Guo X, Zhong H. Synergistic effect of chemo-photothermal therapy using PEGylated graphene oxide. Biomaterials. 2011;32:8555-8561.

67. Misra SK, Kondaiah P, Bhattacharya S, Rao CN. Graphene as a nanocarrier for tamoxifen induces apoptosis in transformed cancer cell lines of different origins. Small. 2012;8:131-143.

68. Kim H, Lee D, Kim J, Kim TI, Kim WJ. Photothermally triggered cytosolic drug delivery via endosome disruption using a functionalized reduced graphene oxide. ACS Nano. 2013;7:67356746.

69.F an X, Jiao G, Zhao W, Jin P, Li X. Magnetic $\mathrm{Fe}_{3} \mathrm{O}_{4}$-graphene composites as targeted drug nanocarriers for $\mathrm{pH}$-activated release. Nanoscale. 2013;5:1143-1152.

70. Qin XC, Guo ZY, Liu ZM, Zhang W, Wan MM, Yang BW. Folic acid-conjugated graphene oxide for cancer targeted chemophotothermal therapy. J Photochem Photobiol B. 2013;120:156-162.

71. Wang Z, Zhou C, Xia J, Via B, Xia Y, Zhang F, Li Y, Xia L. Fabrication and characterization of a triple functionalization of graphene oxide with $\mathrm{Fe}_{3} \mathrm{O}_{4}$, folic acid and doxorubicin as dual-targeted drug nanocarrier. Colloids Surf B Biointerfaces. 2013;106:60-65.

72. Zhou $T$, Zhou $X$, Xing D. Controlled release of doxorubicin from graphene oxide based charge-reversal nanocarrier. Biomaterials. 2014; 35:4185-4194.

73. Song E, Han W, Li C, Cheng D, Li L, Liu L, Zhu G, Song Y, Tan $W$. Hyaluronic acid-decorated graphene oxide nanohybrids as nanocarriers for targeted and $\mathrm{pH}$-responsive anticancer drug delivery. ACS Appl Mater Interfaces. 2014;6:11882-11890.

74. Feng L, Li K, Shi X, Gao M, Liu J, Liu Z. Smart pH-responsive nanocarriers based on nano-graphene oxide for combined chemoand photothermal therapy overcoming drug resistance. Adv Healthc Mater. 2014;3:1261-1271.

75. Xu Z, Zhu S, Wang M, Li Y, Shi P, Huang X. Delivery of paclitaxel using pegylated graphene oxide as a nanocarrier. ACS Appl Mater Interfaces. 2015;7:1355-1363.

76. Tran TH, Nguyen HT, Pham TT, Choi JY, Choi HG, Yong CS, Kim JO. Development of a graphene oxide nanocarrier for dual-drug chemo-phototherapy to overcome drug resistance in cancer. ACS Appl Mater Interfaces. 2015;7:28647-28655.

77. Kundu A, Nandi S, Das P, Nandi AK. Fluorescent graphene oxide via polymer grafting: an efficient nanocarrier for both hydrophilic and hydrophobic drugs. ACS Appl Mater Interfaces. 2015;7:3512-3523.

78. Chauhan G, Chopra V, Tyagi A, Rath G, Sharma RK, Goyal AK. "Gold nanoparticles composite-folic acid conjugated graphene oxide nanohybrids" for targeted chemo-thermal cancer ablation: in vitro screening and in vivo studies. Eur J Pharm Sci. 2017;96:351-361.

79. He H, Li S, Shi X, Wang X, Liu X, Wang Q, Guo A, Ge B, Khan $\mathrm{NU}$, Huang F. Quantitative nanoscopy of small blinking graphene nanocarriers in drug delivery. Bioconjug Chem. 2018;29:36583666.

80. Karimzadeh Z, Javanbakht S, Namazi H. Carboxymethylcellulose/ MOF-5/graphene oxide bio-nanocomposite as antibacterial drug nanocarrier agent. Bioimpacts. 2019;9:5-13.

81. Javanbakht S, Pooresmaeil M, Namazi H. Green one-pot synthesis of carboxymethylcellulose/Zn-based metal-organic framework/ graphene oxide bio-nanocomposite as a nanocarrier for drug delivery system. Carbohydr Polym. 2019;208:294-301.

82. Tiwari H, Karki N, Pal M, Basak S, Verma RK, Bal R, Kandpal ND, Bisht G, Sahoo NG. Functionalized graphene oxide as a nanocarrier for dual drug delivery applications: the synergistic effect of quercetin and gefitinib against ovarian cancer cells. Colloids Surf B Biointerfaces. 2019;178:452-459.

83. Makharza SA, Cirillo G, Vittorio O, Valli E, Voli F, Farfalla A, Curcio M, lemma F, Nicoletta FP, El-Gendy AA, Goya GF, Hampel S. Magnetic graphene oxide nanocarrier for targeted delivery of cisplatin: a perspective for glioblastoma treatment. Pharmaceuticals (Basel). 2019;12(2).

84. Abdollahi Z, Taheri-Kafrani A, Bahrani SA, Kajani AA. PEGAylated graphene oxide/superparamagnetic nanocomposite as a high-efficiency loading nanocarrier for controlled delivery of methotrexate. J Biotechnol. 2019;298:88-97.

85. Dhanavel S, Revathy TA, Sivaranjani T, Sivakumar K, Palani P, Narayanan V, Stephen A. 5-Fluorouracil and curcumin coencapsulated chitosan/reduced graphene oxide nanocomposites against human colon cancer cell lines. Polym Bull. 2019 Mar 15. doi:10.1007/s00289-019-02734-x 
86. Vinothini K, Rajendran NK, Munusamy MA, Alarfaj AA, Rajan M. Development of biotin molecule targeted cancer cell drug delivery of doxorubicin loaded $x$-carrageenan grafted graphene oxide nanocarrier. Mater Sci Eng C Mater Biol Appl. 2019;100:676-687.

87. Liu Z, Robinson JT, Sun X, Dai H. PEGylated nanographene oxide for delivery of water-insoluble cancer drugs. J Am Chem Soc. 2008;130:10876-10877.

88. Bullo S, Buskaran K, Baby R, Dorniani D, Fakurazi S, Hussein MZ. Dual drugs anticancer nanoformulation using graphene oxidePEG as nanocarrier for protocatechuic acid and chlorogenic acid. Pharm Res. 2019;36:91.

89. Mehnert W, Mäder K. Solid lipid nanoparticles. Advanced Drug Delivery Reviews. 2012;64:83-101.

90. Gordillo-Galeano A, Mora-Huertas CE. Solid lipid nanoparticles and nanostructured lipid carriers: a review emphasizing on particle structure and drug release. Eur J Pharm Biopharm. 2018;133:285308.

91. Moss GP, Smith PAS, Tavernier D. Glossary of class names of organic compounds and reactivity intermediates based on structure (IUPAC Recommendations 1995). Pure \&App Chem. 1995;67:13071375.

92. Naseri N, Valizadeh H, Zakeri-Milani P. Solid lipid nanoparticles and nanostructured lipid carriers: structure, preparation and application. Adv Pharm Bull. 2015;5:305-313.

93. Yoon G, Park JW, Yoon IS. Solid lipid nanoparticles (SLNs) and nanostructured lipid carriers (NLCs): recent advances in drug delivery. J Pharm Investig. 2013;43:353-362.
94. Cavalli R, Caputo O, Gasco MR. Solid lipospheres of doxorubicin and idarubicin. Int J Pharm. 1993;89:R9-R12.

95. Morel S, Ugazio E, Cavalli R, Gasco MR. Thymopentin in solid lipid nanoparticles. Int J Pharm. 1996;132:259-261.

96. Yang S, Zhu J, Lu Y, Liang B, Yang C. Body distribution of camptothecin solid lipid nanoparticles after oral administration. Pharm Res. 1999;16:751-757.

97. Choi WI, Kim JY, Kang C, Byeon CC, Kim YH, Tae G. Tumor regression in vivo by photothermal therapy based on gold-nanorodloaded, functional nanocarriers. ACS Nano. 2011;5:1995-2003.

98. Kang B, Okwieka P, Schöttler S, Winzen S, Langhanki J, Mohr K, Opatz T, Mailänder V, Landfester K, Wurm FR. Carbohydrate-based nanocarriers exhibiting specific cell targeting with minimum influence from the protein corona. Angew Chem Int Ed Engl. 2015;54:7436-7440.

99. Sack M, Alili L, Karaman E, Das S, Gupta A, Seal S, Brenneisen P. Combination of conventional chemotherapeutics with redox-active cerium oxide nanoparticles-a novel aspect in cancer therapy. Mol Cancer Ther. 2014;13:1740-1749.

100. Hampel S, Kunze D, Haase D, Krämer K, Rauschenbach M, Ritschel M, Leonhardt A, Thomas J, Oswald S, Hoffmann V, Büchner B. Carbon nanotubes filled with a chemotherapeutic agent: a nanocarrier mediates inhibition of tumor cell growth. Nanomedicine (Lond). 2008;3:175-182. 